\title{
Species composition, substrate specificity, and seasonal abundance of periphytic algae in a tropical riverine system- Periyar, India
}

\author{
Blessy JOHN' ${ }^{\circledR}$, R. Sunil KUMAR
}

Cite this article as:

John, B. Kumar, R.S. (2021). Species composition, subtrate specifity, and seasonal abundance of peripphytic algae in atropical riverine system-Periya, India. Aquatic Research, 4(2), 129-144. https://doi.org/10.3153/AR21010

Mahatma Gandhi University, Catholicate College, Department of Zoology Pathanamthitta- 689645, Kerala, India

ORCID IDs of the author(s): B.J. 0000-0002-0037-8391 R.S.K. 0000-0003-2485-8936

Submitted: 31.07 .2020

Revision requested: 16.09 .2020

Last revision received: 24.09 .2020

Accepted: 03.10.2020

Published online: 09.01.2021

Correspondence:

Blessy JOHN

E-mail: bessyiohn87@gmail.com

\section{ABSTRACT}

The study was conducted to assess the species composition, substrate specificity, and seasonal abundance of periphytic algae from the river Periyar. Monthly samples were collected for one year (June 2016 - May 2017) from different substrates of five selected stations. Eight physicochemical variables such as temperature, dissolved oxygen, $\mathrm{pH}$, conductivity, chloride, sulfate, nitrate, and phosphate were also monitored during the study. Taxonomic studies recorded 156 species of periphytic algae belonging to 56 genera, 36 families, and 5 classes. Naviculaceae was the most abundant family followed by Fragilariaceae and Pinnulariaceae. The principal component analysis revealed the dominance of periphytic algae in the pre-monsoon period. Canonical correspondence analysis indicates $\mathrm{pH}$, conductivity, and sulfate plays a crucial role in periphytic algal assemblages. Correspondence analysis and percentage abundance among different substrates showed the preference of leaf substrate for primary colonization and subsequent succession. The study signifies the importance of substratum and environmental variables in the dynamics of periphytic algal community composition and abundance.

Keywords: Substratum, Periphytic algae, Principal component analysis, Periyar river

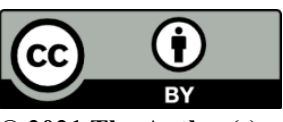

(C) 2021 The Author(s) 


\section{Introduction}

Periphyton forms an important component in the functioning of all aquatic ecosystems; it is cosmopolitan in distribution and thrives well in adverse conditions of rivers and streams. It is a micro-ecosystem found on the free surfaces of submerged substrata in aquatic bodies consists of algae, protozoa, bacteria, fungi, and small metazoans (Satkauskiene \& Glasaite, 2013). Algae possess a pivotal position among the periphytic organisms due to their abundance and richness ( $\mathrm{Ru}-$ sanov \& Stanislavskaya, 2012). Periphytic biofilm appears mostly as a green mat due to the dominant algal assemblages. Perihytic algae act as a power source for all aquatic biota and as a major regulator of nutrient fluxes since it forms the basis of all food web interactions.

Periphyton significantly contributes to bio-manipulation monitoring; since it quickly responds to slight variations in the environmental conditions, its short life cycle, and abundance in the littoral zones of aquatic ecosystems (Wu, 2017; Kanavillil \& Kurisseryl, 2013). Periphytic algal community composition varies greatly in spatial and temporal scale by several biotic and abiotic factors such as temperature, light availability, nutrient influx, substrate type, water currents, submersion time, and grazing (Albay \& Akcaalan, 2008; De Souza et al., 2015). Periphytic biofilm can be found attached to dead or living substrates such as sediments, rocks, pebbles, macrophytes, and animal bodies (Wu, 2017).

Periphyton gains more attention in the riverine ecosystem due to its stable nature. Streams and rivers are continuously moving and any suspended particle in it can reach the sea within a few days (Srivastava et al., 2019; Gurumayum \& Goswami, 2013). Sessile life forms are spatially compacted in define limits hence periphytic algal assemblages dominate more than planktonic forms in rivers compared to lakes and reservoirs (Franca et al., 2011). Even though periphytons play a crucial role in aquatic health; research works on periphyton in freshwater rivers of Kerala are too limited. Most of the hydrological studies concentrate on the planktonic forms and information on periphytic forms is scarce which is more important as they are found mostly attached to the more productive littoral zones of aquatic ecosystems.

Periyar the longest river of Kerala, on its course of flow passes through lush green forests, agricultural areas, human settlement regions, townships, and industrial areas. Thus the hydrology, flora, and fauna of the river Periyar are greatly influenced by the geographical areas next to the watercourse. The study sites were chosen from the middle and lower reaches of the river Periyar; the lower reaches of the river is a hub of major industrial and commercial activities while upper reac- hes are comparatively less influenced by anthropogenic activities. The study aims to understand the species composition, substrate specificity, and seasonal abundance of periphytic algae in relation to the environmental parameters from the selected stations of river Periyar.

\section{Material and Methods}

\section{Study Area}

Periyar a perennial river of Kerala originates from Sivagiri peaks of Western Ghats and has a total length of $244 \mathrm{~km}$. Periyar river is also known as 'Lifeline of Kerala' forms the backbone to the economy of Kerala by providing water for drinking, agricultural purposes, and electrical power generation.

Five sampling stations were selected along different stretches of river Periyar to assess the periphytic algal composition (Figure 1). Station 1 (S1): Pooyamkutty; Station 2 (S2): Kuttampuzha; Station 3 (S3): Thattekadu; Station 4 (S4): Aluva and Station 5 (S5): Varappuzha (Table 1). Station 1, 2 , and 3 were located in the middle stretches of the Periyar river. These stations mainly receive agricultural runoff, domestic wastes, and laundry wastes from the nearby area. Stations 4 and 5 are located in the lower stretches and receive an enormous amount of sewage, garbage dumps, and industrial effluents from nearby towns and industries. Station 5 is also influenced by seawater intrusion during tidal cycles.

\section{Sampling Procedure}

\section{Biological analysis}

Samples were collected for a one-year duration (June 2016 May 2017) from five selected stations. Five different substrata such as leaf, root, rock, wall, and log were chosen from each station and $5 \mathrm{~cm}^{2}$ areas were scrapped from the selected substrate using a scalpel, brush, or blade. The scrapped contents were rinsed into a tray using distilled water and then transferred to a sampling bottle via a funnel. The samples were preserved with $4 \%$ of formalin and made upto $10 \mathrm{~mL}$ using distilled water (Biggs \& Kilroy, 2000). One $\mathrm{mL}$ of the preserved sample was placed on a Sedgwick rafter counting chamber for enumeration. The counting chamber was then examined under an inverted microscope (Carl Zeiss Primovert, Germany) equipped with phase contrast. Sedgwick rafter consists of 1000 cells and each cell contains a considerable number of algal cells. For convenience 5 rows consisting of 250 cells were counted and the results were expressed in the number of individuals $/ \mathrm{cm}^{2}$. Measurements and photographs of algal cells were taken and identified using standard books, 
key, and literature (Adhikary \& Das, 2012; Edmondson, 1959; John \& Francis, 2012; Karthick et al., 2013).

\section{Physicochemical analysis}

Physicochemical parameters such as $\mathrm{pH}$, conductivity, temperature, and dissolved oxygen (DO) were determined on-site using a Cyberscan PCD 650 multiparameter probe (Eutec instruments, Singapore). Water samples were brought to the lab under $4^{\circ} \mathrm{C}$ and dark for the determination of remaining water quality parameters. The concentration of sulfate, phosphate, chloride, and nitrate was determined using standard methods (APHA, 2005).

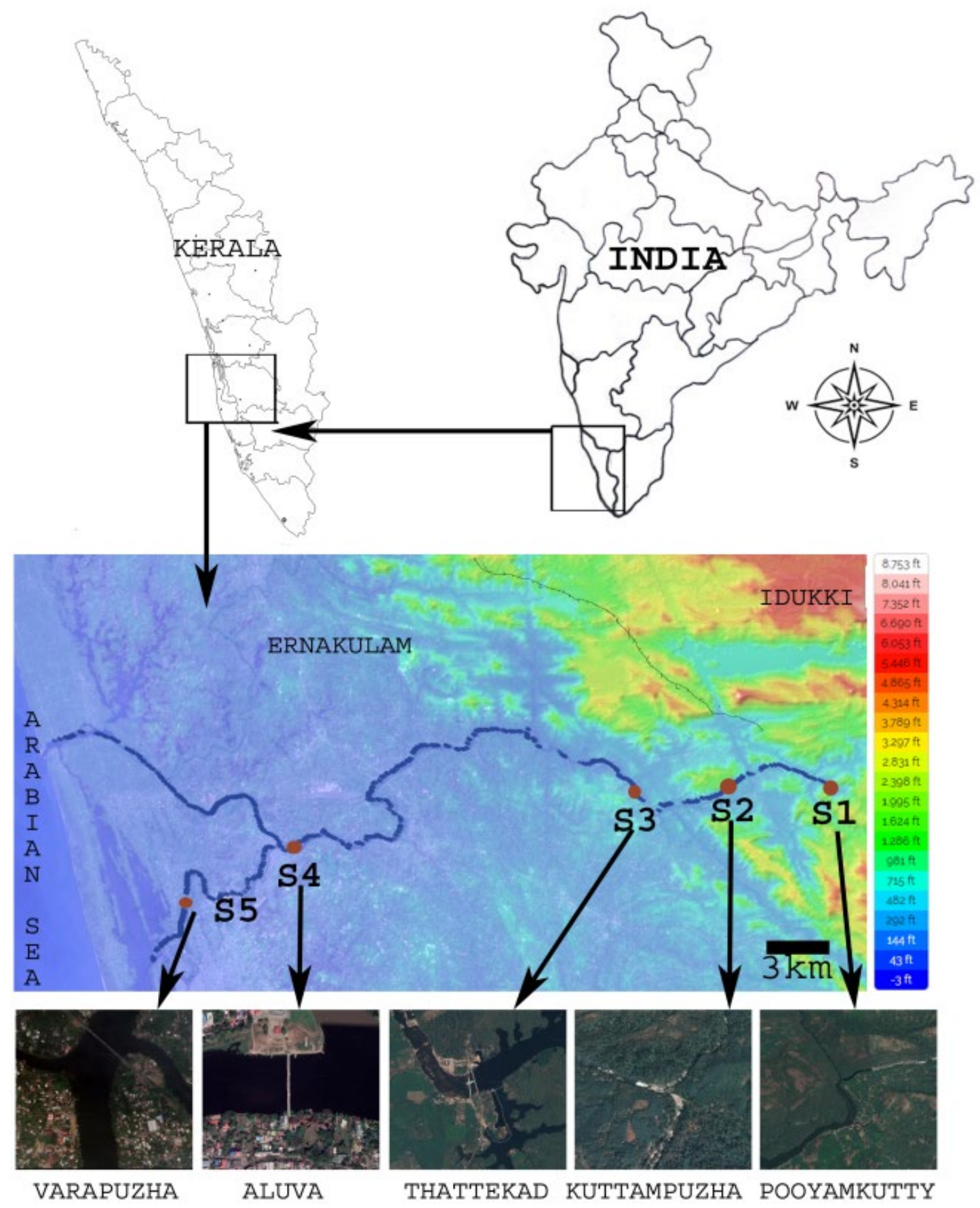

Figure 1. Map showing the selected study sites along the river Periyar 


\section{Statistical Analysis}

Statistical analyses were performed using the software PAST version 318. Environmental data and periphytic algal data were subjected to normality tests using Monte-Carlo 999 permutation test. Principal Component Analysis (PCA) was conducted to know how the periphytic algal composition varies among monsoon, pre-monsoon, and post-monsoon seasons. To down weigh the contribution of abundant species, periphytic algal data were square-root transformed before analysis. Canonical Correspondence Analysis (CCA) was performed to demonstrate the relationship between periphytic algal assemblages and environmental variables. Environmental variables were subjected to Pearson's (Linear $r$ ) correlation to identify the significant variables $(\mathrm{p}<0.05)$ and were standardized using the formula (X-mean)/SD. Correspondence Analysis (CA) is also an ordination method like PCA and is used to determine the preferred distribution range of algal families to a particular substrate and station. Cluster analysis was performed using the algorithm UPGMA (Bray-Curtis similarity index) to know the percentage of similarity within the substrata and stations regarding periphytic algal abundance and distribution.

Table 1. Geographical coordinates of selected stations

\begin{tabular}{|l|l|l|}
\hline Stations & Latitude & Longitude \\
\hline S1 (Pooyamkutty) & $10.1605^{\circ} \mathrm{N}$ & $76.7769^{\circ} \mathrm{E}$ \\
\hline S2 (Kuttampuha) & $10.1525^{\circ} \mathrm{N}$ & $76.7396^{\circ} \mathrm{E}$ \\
\hline S3 (Thattekadu) & $10.1040^{\circ} \mathrm{N}$ & $76.7005^{\circ} \mathrm{E}$ \\
\hline S4 (Aluva) & $10.0758^{\circ} \mathrm{N}$ & $76.2714^{\circ} \mathrm{E}$ \\
\hline S5 (Varappuzha) & $10.1004^{\circ} \mathrm{N}$ & $76.3570^{\circ} \mathrm{E}$ \\
\hline
\end{tabular}

\section{Results and Discussion}

Periphyton itself is a micro-ecosystem with multiple interactions among the organisms present in it. Algae form the major proportion of periphytic biota contributing significantly towards carbon sequestration and nutrient cycling (Albay \& Akcaalan, 2008). Periphytic algae can be found in all types of aquatic ecosystems due to its wide range of tolerance to adverse environmental conditions and varied habitats $(\mathrm{Wu}, 2017)$. The present study evaluated the seasonal distribution, substrate specificity, and habitat preference of periphytic algae with the environmental parameters.

\section{Abiotic Parameters}

Eight physicochemical parameters such as temperature, $\mathrm{pH}$, dissolved oxygen, conductivity, chloride, sulfate, phosphate, and nitrate were monitored during the study period (Table 2). Correlations between the selected environmental parameters were provided in table 3 . The temperature did not show much variation among selected stations even though lower reaches recorded high values of temperature, especially in the pre-monsoon period. Temperature showed a positive correlation with phosphate $(\mathrm{r}=+0.946)$ and nitrate $(\mathrm{r}=+0.918)$ at 0.05 level of significance. Dissolved oxygen values showed a gradual reduction from stations 1 to 5 in all seasons and the values were high in the middle reaches especially in the monsoon period. A negative correlation of DO with temperature $(\mathrm{r}=-0.983)$ and phosphate $(\mathrm{r}=-0.982)$ was observed at 0.01 level of significance. $\mathrm{pH}$ values recorded at station 5 were slightly alkaline compared to other stations. $\mathrm{pH}$ showed a positive correlation with conductivity $(\mathrm{r}=+0.952), \quad$ sulphate $(\mathrm{r}=+0.951)$ and chloride $(\mathrm{r}=+0.949)$ at 0.05 level of significance. Station 5 exhibited a marked difference in conductivity from the rest of the stations and the premonsoon period recorded maximum conductivity values. Conductivity showed a positive correlation with $\mathrm{pH}$ $(\mathrm{r}=+0.952)$ at 0.05 level of significance. A high correlation of conductivity with sulfate $(\mathrm{r}=+0.999)$ and chloride $(\mathrm{r}=+0.999)$ was recorded at 0.01 level of significance. Chloride values exhibited a gradual increase from monsoon to pre-monsoon periods. A positive correlation of chloride with $\mathrm{pH}(\mathrm{r}=+0.949)$ was reported at a 0.05 level of significance. Sulfate $(\mathrm{r}=+0.999)$ and conductivity $(\mathrm{r}=+0.999)$ values exhibited a positive correlation at 0.01 level of significance.

Nitrate has its highest value at station 4 and the pre-monsoon period marked the highest nitrate concentrations in all stations. Nitrate exhibits a positive correlation with temperature $(\mathrm{r}=+0.918)$ at 0.05 level of significance. Phosphate values showed a gradual increase from monsoon to pre-monsoon periods. Phosphate showed a positive correlation with temperature $(\mathrm{r}=+0.946)$ at 0.05 level of significance and a negative correlation with DO $(r=-0.982)$ at 0.01 level of significance. Station 5 showed a significant difference in sulfate values from the rest of the stations and the pre-monsoon period recorded high values. Sulfate showed a positive correlation 
with $\mathrm{pH}(\mathrm{r}=+0.951)$ at 0.05 level of significance. A high positive correlation of sulfate with conductivity $(\mathrm{r}=+0.999)$ and chloride $(\mathrm{r}=+0.999)$ was recorded at 0.01 level of significance.

\section{Periphytic Algal Assemblages of River Periyar}

Taxonomic studies on the periphytic algal composition of river Periyar revealed 156 species belonging to 56 genera, 36 families, and 5 classes (Table 4). Of the 36 families reported, Naviculaceae was found to be the most abundant one with $19.71 \%$ of periphytic algal species followed by Fragilariaceae (17.71\%) and Pinnulariaceae $(9.60 \%)$. All of these abundant families belong to the class Bacillariophyceae (Figure 2). Bacillariophyceae have specialized modifications and fixative structures for attaching to a varied substrate and they are considered as the pioneering colonizers in lotic ecosystems (Biggs, 1996). Many species of Bacillariophyceae were reported as fast and efficient colonizers of the aquatic system (Franca et al., 2011). The abundance of Bacillariophyceae due to its competitive ability towards adverse conditions in tropical ecosystems was reported by Cetto et al. (2004). Studies regarding the composition of periphytic algae from the Ganga river (Srivastava et al., 2019) and the Nemunas River (Satkauskiene \& Glasaite, 2013) reported the dominance of Bacillariophyceae. Oterler (2016) and Kanavillil and Kurisseryl (2013) also reported the dominance of diatoms from their studies on different aquatic ecosystems.

\section{Seasonal Distribution Based on Principal Component Analysis (PCA)}

PCA showed the difference in the distribution of the periphytic algal assemblages among three seasons. Algal families were represented by vectors; the orientation and spacing of these vectors on the ordination space indicate the magnitude of dispersion of algal families among different seasons (Figure 3). Here vector for the Naviculaceae family showed maximum dispersion from the origin and showed maximum periphytic algal abundance for the pre-monsoon period. The least represented families form a cluster near the origin. Months were denoted by the dots on the ordination space which forms convex-hulls for corresponding seasons. The area enclosed by the convex hull denotes the variance of that particular group and here convex-hull for pre-monsoon shows maximum variance which signifies the dominance of the pre-monsoon period over other seasons. Principal Component (PC) 1 and 2 itself contributes to $75.22 \%$ of the variation in the data. The covariance obtained by eigenvalue showed $67.47 \%$ of the variance for the horizontal axis and $7.75 \%$ of the variance for the vertical axis. PC1 has its highest loading in the pre-monsoon season (March, April, and February). Naviculaceae and Fragilariaceae families contribute to higher scores for PC1 and thus signify the role of these families in the total algal abundance during the pre-monsoon period.

During the pre-monsoon period, generally in all lotic ecosystems water becomes more stable, organic, and nutrient load increases. The increased temperature enhances the rate of decomposition and helps in subsequent phytoplankton production (Hajong \& Ramanujam, 2018; Kaparapu \& Geddada, 2013). Increased water temperature and light availability in the pre-monsoon period result in the abundance of periphytic algae (Sohani, 2015). Low temperature, increased water currents, cloudy weather, and low nutrient availability may be the main causes of decreased periphytic algal abundance reported during monsoon season (Kaparapu \& Geddada, 2013). As the water current increases the chances of washing off the periphytic mat increase, thereby affecting the succession pattern of the periphytic colonizers. These factors mainly contribute to the increased periphytic algal abundance in pre-monsoon and decreased abundance in monsoon. From their work on the Nemunas river and Kaunas lagoon, Satkauskiene and Glasaite (2013) reported the abundance of periphytic algae during the pre-monsoon period. Many authors agree with the dominance of the pre-monsoon period in association with periphytic algal abundance (Oterler, 2016; Franca et al., 2011; Srivastava et al., 2019). 
Table 2. Physicochemical parameters monitored from five selected stations of river Periyar

\begin{tabular}{|c|c|c|c|c|c|c|c|c|c|}
\hline & $\begin{array}{l}\tilde{y} \\
0 \\
\tilde{D} \\
\tilde{D}\end{array}$ & 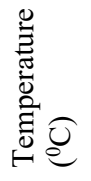 & $\stackrel{T}{2}$ & 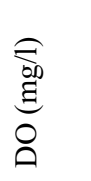 & 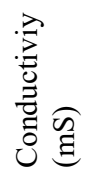 & 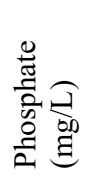 & 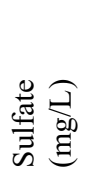 & 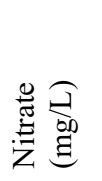 & 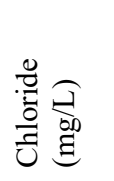 \\
\hline \multirow[t]{3}{*}{ S1 } & Monsoon & 25.7 & 6.6 & 8.0 & 0.013 & 0.180 & 0.123 & 0.279 & 62.48 \\
\hline & Post-monsoon & 25.0 & 6.4 & 8.3 & 0.019 & 0.520 & 0.252 & 0.434 & 74.98 \\
\hline & Pre-monsoon & 26.2 & 6.1 & 7.8 & 0.03 & 1.060 & 0.172 & 3.600 & 99.97 \\
\hline \multirow[t]{3}{*}{$\mathrm{S} 2$} & Monsoon & 25.9 & 6.7 & 7.8 & 0.039 & 0.157 & 0.143 & 0.327 & 62.48 \\
\hline & Post-monsoon & 26.0 & 6.4 & 8.1 & 0.019 & 0.554 & 0.300 & 0.446 & 74.98 \\
\hline & Pre-monsoon & 27.1 & 6.0 & 7.5 & 0.029 & 1.072 & 0.266 & 5.000 & 87.47 \\
\hline \multirow[t]{3}{*}{$\mathrm{S} 3$} & Monsoon & 26.4 & 6.9 & 7.6 & 0.015 & 0.204 & 0.200 & 0.375 & 74.98 \\
\hline & Post-monsoon & 27.7 & 6.6 & 7.5 & 0.024 & 0.686 & 0.331 & 0.506 & 74.98 \\
\hline & Pre-monsoon & 28.0 & 6.3 & 7.1 & 0.033 & 1.160 & 0.200 & 5.900 & 99.97 \\
\hline \multirow[t]{3}{*}{ S4 } & Monsoon & 27.6 & 7.0 & 7.2 & 0.024 & 0.464 & 0.242 & 1.233 & 87.47 \\
\hline & Post-monsoon & 29.5 & 6.0 & 6.8 & 0.038 & 0.997 & 0.458 & 2.652 & 99.97 \\
\hline & Pre-monsoon & 29.7 & 5.8 & 6.5 & 0.043 & 1.511 & 0.369 & 9.805 & 112.46 \\
\hline \multirow[t]{3}{*}{ S5 } & Monsoon & 27.9 & 7.4 & 6.8 & 24.00 & 0.663 & 10.30 & 0.812 & 349.89 \\
\hline & Post-monsoon & 30.1 & 7.3 & 6.3 & 46.70 & 1.323 & 40.90 & 2.960 & 1487.04 \\
\hline & Pre-monsoon & 30.0 & 7.5 & 5.6 & 49.10 & 1.600 & 60.90 & 6.953 & 1928.78 \\
\hline
\end{tabular}

Table 3. Correlation between different physicochemical parameters along the study sites of Periyar river.

\begin{tabular}{|l|l|l|l|l|l|l|l|}
\hline & Temperature & \multicolumn{1}{|c|}{$\mathrm{pH}$} & D.O & $\begin{array}{c}\text { Conductiv- } \\
\text { ity }\end{array}$ & Phosphate & Sulphate & Nitrate \\
\hline Temperature & & & & & & & \\
\hline $\mathrm{pH}$ & 0.525 & & & & & & \\
\hline D.O & $-0.983^{* *}$ & -0.660 & & & & & \\
\hline Conductivity & 0.628 & $0.952^{*}$ & -0.760 & & & & \\
\hline Phosphate & $0.946^{*}$ & 0.661 & $-0.982^{* *}$ & 0.795 & & & \\
\hline Sulphate & 0.631 & $0.951^{*}$ & -0.760 & $0.999^{* *}$ & 0.797 & & \\
\hline Nitrate & $0.918^{*}$ & 0.182 & -0.860 & 0.360 & 0.848 & 0.364 & \\
\hline Chloride & 0.641 & $0.949^{*}$ & -0.770 & $0.999^{* *}$ & 0.805 & $0.999^{* *}$ & 0.376 \\
\hline$* *$ Correlation is significant at the 0.01 level (2-tailed). \\
\hline *. Correlation is significant at the 0.05 level (2-tailed). \\
\hline
\end{tabular}

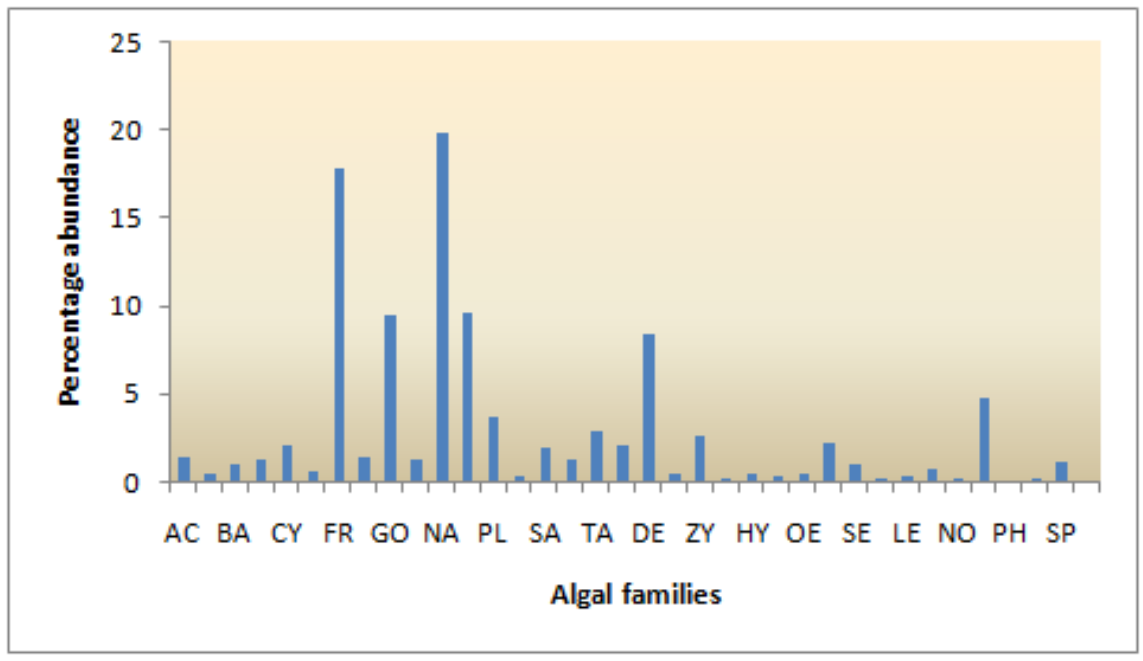

Figure 2. Percentage abundance of periphytic algal families from the river Periyar 
Table 4. Taxonomic distribution of periphytic algal families identified from river Periyar

\begin{tabular}{|c|c|c|c|}
\hline $\begin{array}{r}\text { FAMILY } \\
\end{array}$ & SPECIES & FAMILY & SPECIES \\
\hline \multirow[t]{2}{*}{ ACHNANTHACEAE (AC) } & Achnanthes brevipes $\mathrm{C}$. Agardh & & C. spinuliferum West \& G.S.West \\
\hline & A .inflata (Kütz.) Grunow & & C. turgidum Brébisson ex Ralfs \\
\hline AMPHIPLEURACEAE (AM) & Frustulia franguelli Manguin & & Desmidium quadratum Nordstedt \\
\hline \multirow[t]{4}{*}{ BACILLARIACEAE (BA) } & Bacillaria paxillifer (O.F.Müller) T.Marsson & & Desmidium sp. \\
\hline & Nitzschia sigmoidea (Nitzsch) W.Smith & & Euastrum anastum Ehrenberg ex Ralfs \\
\hline & Nitzschia sp. & & E. coralloides Joshua \\
\hline & Tryblionella constricta $\mathrm{W}$.Gregory & & E. didelta Ralfs \\
\hline \multirow[t]{2}{*}{ CALENULACEAE (CA) } & Amphora ovalis (Kützing) Kützing & & E. dubium Nägeli \\
\hline & Amphora sp. & & Hyalotheca dissiliens Brébisson ex Ralfs \\
\hline \multirow[t]{2}{*}{ CYMBELLACEAE (CY) } & Cymbella affinis Kützing & & Hyalotheca sp. \\
\hline & C. bengalensis Grunow & & Micrasteriasis foliacea Bailey ex Ralfs \\
\hline DIPLOEIDACEAE (DI) & Diploneis elliptica (Kützing) Cleve & & M. mahabuleswarensis J.Hobson \\
\hline \multirow{5}{*}{ FRAGILARIACEAE (FR) } & Asterionella sp. & & M. pinnatifida Ralfs \\
\hline & Fragilaria capucina Desmazières & & M. radians W.B.Turner \\
\hline & F.virescens Ralfs & & Pleurotaenium sp. \\
\hline & Synedra acus Kützing & & Spondylosium planum (Wolle) West \& G.S.West \\
\hline & S. ulna (Nitzsch) Ehrenberg & & Staurastrum bicorne Hauptfleisch \\
\hline EUNOTIACEAE (EU) & Eunotia sp. & & S. crenulatum (Nägeli) Delponte \\
\hline \multirow[t]{6}{*}{ GOMPHONEMATACEAE (GO) } & Gomphonema angustatum (Kützing) Rabenhorst & & S. cyrtocerum Brébisson \\
\hline & G. gracile Ehrenberg & & S. gracile Ralfs ex Ralfs \\
\hline & G. grunowii R.M.Patrick \& Reimer & & S. nodulosum Prescott \\
\hline & G. intricatum Kützing & & S. perundulatum Grönblad \\
\hline & G. parvulum (Kützing) Kützing & & S. pinnatum W.B.Turner \\
\hline & G. telegraphicum Kützing & & S. spiniceps Willi Krieger \\
\hline \multirow[t]{3}{*}{ MELOSIRACEAE (ME) } & Melosira granulate (Ehrenberg) Ralfs & & S. tohopekaligense Wolle \\
\hline & M. monoliformis C. Agardh & & S. zonatum Børgesen \\
\hline & Melosira Sp. & & Staurodesmus conatus (P.Lundell) Thomasson \\
\hline \multirow[t]{4}{*}{ NAVICULACEAE (NA) } & Navicula protracta Grunow & & S. dickiei (Ralfs) Lillieroth \\
\hline & N. microspora Kant and Gupta & MESOTAENIACEAE (MS) & Netrium digitis Brébisson ex Ralfs \\
\hline & N. radiosa Kützing & ZYGNEMATOPHYCEAE (ZY) & Mougeotia operculata Transeau \\
\hline & N. striolata (Grunow) Lange-Bertalot & & Mougeotia sp. \\
\hline \multirow[t]{8}{*}{ PINNULARIACEAE (PI) } & Pinnularia biceps W.Gregory & & Spirogyra baileyi Schmidle \\
\hline & P. braunii Cleve & & S. chungkingensis Jao \\
\hline & P. divergens $\mathrm{W}$. Smith & & S. elongate (Vaucher) Dumortier \\
\hline & P. gibba (Ehrenberg) Ehrenberg & & S. hyaline Cleve \\
\hline & P. major (Kützing) Rabenhorst & & S. lutetiana Petit \\
\hline & P. microstauron (Ehrenberg) Cleve & & S. maravillosa Transeau \\
\hline & P. nodosa (Ehrenberg) W.Smith & & S. nawashini Kasanowsky \\
\hline & P. viridis (Nitzsch) Ehrenberg & & S. parvula (Transeau) Czurda \\
\hline
\end{tabular}




\section{Aquat Res 4(2), 129-144 (2021) • https://doi.org/10.3153/AR21010}

\begin{tabular}{|l|l|}
\hline PLEUROSIGMATACEAE (PL) & Gyrosigma acuminatum (Kützing) Rabenhorst \\
\hline
\end{tabular}

\begin{tabular}{|l|l}
\hline & \\
\hline & \\
\hline & \\
\hline & \\
\hline & \\
\hline
\end{tabular}
J.W. Griffith \& Henfrey G. eximum (Thwaites) Boyer

G. obtusatum (Sullivant \& Wormley) C.S.Boyer G. scalproides (Rabenhorst) Cleve

SIRURELLACEAE (SI)

Pleurosigma lange -bertalotii Karthick \& Kociolek Pleurosigma sp.

STAURONEIDACEAE (SA)

STEPHANODISCACEAE (ST) Sirurella robusta Ehrenberg

Sirurella sp.

STEPHANODISCACEAE $($ ST)

Stauroneis acuta W. Smith

S. anceps Ehrenberg

S. phoenicenteron (Nitzsch) Ehrenberg

CLOSTERIACEAE (CL) Cyclotella sp.

TOSTERIACEAE $(\mathrm{CL})$

Closterium acerosum Ehrenberg ex Ralf

C. dianae Ehrenberg ex Ralfs

C. leibleinii Kützing ex Ralfs

\begin{tabular}{|l|l|}
\hline C. monoliferum Ehrenberg ex Ralfs \\
\hline
\end{tabular}

C. parvulum Nägeli

C. tumidulum F.Gay

\begin{tabular}{|l|l|}
\hline & C. venus Kützing ex Ralfs \\
\hline DESMIDACEAE (DE) & Cosmrium auriculatum Reinsch \\
\hline
\end{tabular}

C. botrytis Meneghini ex Ralfs

\begin{tabular}{|l|l|}
\hline & C. circularae Reinsch \\
\hline & C. contractum O.Kirchner \\
\hline & C. decoram West G.W.St
\end{tabular}

C. decoratum West \& G.S.Wes

C. formulosum Hoff

C. javanicum Nordstedt

C. margaritatum (Lund.) Roy \& Bissett

C. obsoletum (Hantzsch) Reinsch

C. pardalis Cohn

C. perforatum P.Lundell

C. pluriradians Scott, A.M. \& Grönblad

C. porteanum W.Archer

C. pseudopyrimidatum P.Lundell

C. psuedobroomei Wolle

C. psuedoconnatum Nordstedt

C. quadriverrucosum West \& G.S.Wes

C. quadrum P.Lundel

C. speciosum P.Lunde
Research Article

Zygnema gangeticum Bhashyakarla Rao

Gonium compactum M.O.P.Iyengar

Pediastrum boryanum (Turpin) Meneghin

P. duplex Meyen

P. simplex Meyen

\begin{tabular}{l|l} 
MICROSPORACEAE (MI) & Microspora pachyderama (Wille) Lagerheim
\end{tabular}

OEDOGONIACEAE (OE) Microspora sp.

Oedogonium echinospermum A.Braun ex Hirn

Oedogonium sp.

SCENEDESMACEAE (SC) $\quad$ Scenedesmus denticulats Lagerheim

S. perforates Lemmermann

S. prismaticus Brühl \& Biswas

S. granulates West \& G.S.West

S. quadricauda (Turpin) Brébisson

S. quadrispina Chodat

\begin{tabular}{l|l}
\hline SELENASTRACEAE (SE) & Ankistrodesmus benardii Komárek \\
\hline
\end{tabular}

Ankistrodesmus sp.

Selenastrum gracile Reinsch

\begin{tabular}{l|l} 
Chroococcus sp. \\
\hline
\end{tabular}

LEPTOLYNGBYCEAE (LE) $\quad$ Leptolyngbya lurida (Gomont) Anagnostidis \& Komárek

MERISMOPEDIACEAE (MR) $\quad$ Merismopedia tenuissima Lemmermann

\begin{tabular}{l|l} 
NOSTOCACEAE (NO) & Anabaena sp.
\end{tabular}

OSCILLATORIACEAE (OS) $\quad$ Lyngbya dendrobia Brühl \& Biswas

L. sordida Gomont

Oscillitoria constricta Szafer

O. princeps Vaucher ex Gomont

O.rubescens De Candolle ex Gomont

O.salina Biswas

Oscillitoria sp.

O.subbrevis Schmidle

O.tenius C.Agardh ex Gomont

Phormidium crassior (Behre) Anagnostidis

Phormidium sp.

PHORMIDIACEAE (PH)

Planktothrix rubrscens De Candolle ex Gomont

Symploca hydnoides Kützing ex Gomont

SCYTONEMATACEAE (SY)

SPIRULINACEAE (SP)

Scytonema rivulare Borzì ex Bornet \& Flahault

Spirulina major Kützing ex Gomont

\begin{tabular}{l|l} 
EUGLENACEAE (EU) & Phacus sp.
\end{tabular} 


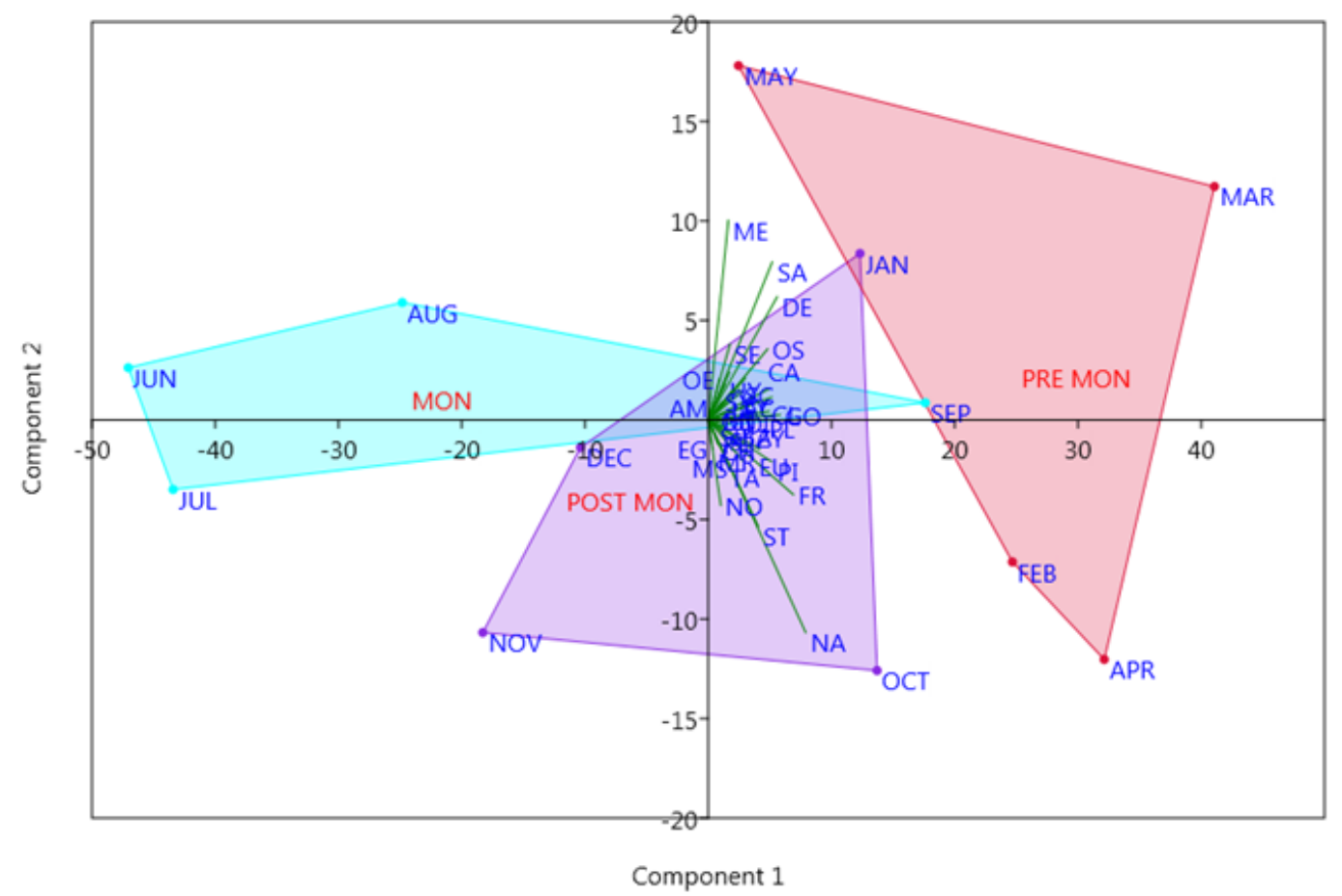

Figure 3. PCA depicting periphytic algal community composition and seasonal abundance. Algal families were represented by the vectors radiating from the origin. Dots on the plot represents months(JUN-June, JUL-July, AUG-August, SEPSeptember, OCT-October, NOV- November, DEC- December, JAN- January, FEB- February, MAR-March, APRApril) and convex-hull denotes 95\% confidence level for corresponding seasons(MON-monsoon, POST MON-postmonsoon, PRE MON- re-monsoon). Abbreviations for algal families were provided in table 2.

\section{Canonical Correspondence Analysis (CCA)}

Canonical Correspondence Analysis (CCA) was conducted to know the relation existing between the eight environmental parameters studied and 36 periphytic algal families reported. Eigenvalues of axis1 (lambda $=$ 0.14 ) and axis $2($ lambda $=0.07)$ itself explain $73.44 \%$ of the relationship between the data. In the ordination plot, environmental parameters were represented by vectors radiating from the origin, and algal families were represented by dots on the space (Figure 4). The vector for dissolved oxygen (DO) is an obtuse angle with all other vectors; illustrates that DO is negatively correlated with all other environmental variables. Vectors for nitrate and phosphate form an acute angle denote the positive correlation with each other; likely conductivity, chloride, temperature, and sulfate were positively correlated.

Axis 1 forms positive association with $\mathrm{pH}(\mathrm{r}=0.778)$, conductivity $(\mathrm{r}=0.626)$, sulphate $(\mathrm{r}=0.626)$, temperature $(r=0.618)$, phosphate $(r=0.576)$ and with station 5. Periphytic algal families like Pinnulariaceae, Cymbellaceae, Oscillatoriaceae, Euglenaceae, Acanthaceae, Calenulaceae, Stephanodiscaceae, Spirulinaceae, and Bacillariaceae also have positive loadings for axis 1 and thus illustrate the role of $\mathrm{pH}$, temperature, conductivity, sulfate, and phosphate in the distribution of these algal families around station 5. Acute angles formed by these environmental vectors illustrate a positive correlation with each other. Station 5, Varappuzha is located in the 
lower stretches of river Periyar and is continuously receiving an enormous amount of sewage, garbage dumps, and industrial effluents from nearby industries and towns resulted in the increased values for phosphate, sulfate, and conductivity at this station. This station also receives a considerable amount of seawater during tidal cycles account for the increased chloride, conductivity, and $\mathrm{pH}$. Satkauskiene and Glasaite (2013) from their studies on the Nemunas river, Lithuania reported that higher temperatures and alkaline $\mathrm{pH}$ favor the growth of periphyton. A significant positive association of phytoplankton with water temperature, $\mathrm{pH}$, and chlorides were reported by Kaparapu and Geddada (2013) from their studies conducted on a tropical freshwater system. Axis 1 forms a negative association with dissolved oxygen $(r=-0.653)$ and with stations 1 and 2. Periphytic algal families Closteriaceae, Chrococcaceae, Selenastraceae, Desmidaceae, Goniaceae, and Nostocaceae also have negative loadings for axis 1 , and clearly define the role of DO in the distribution and abundance of these families around Stations 1 and 2. These stations were located in the middle stretches of river Periyar and DO values recorded from these regions were comparatively higher than other stations. Oterler (2016) reported a negative correlation of phytoplankton with DO from his studies on the Tundzha river, Turkey. Kaparapu and Geddada (2013) also agree with the negative correlation of DO with periphytic algal assemblages as per their studies on the Riwada reservoir, Andra Pradesh.

\section{Station Wise Distribution of Periphytic Algae}

Percentage abundance of station wise distribution of periphytic algae follows the order; station $4(\mathrm{~S} 4)>$ station $1(\mathrm{~S} 1)>$ station $5(\mathrm{~S} 5)>$ station $2(\mathrm{~S} 2)>$ station $3(\mathrm{~S} 3)$ (Figure 5). The maximum number of species was reported from station $4(29.52 \%)$ and minimum from station 3 (12.54\%). Navicula micropspora, N. protracta, Fragilaria virescens, $F$. capucina, Synedra ulna, $S$. acusa, Gomphonema grunowii, Pinnularia viridis and Tabellaria floculosa were the dominant species reported from station 4.

Correspondence analysis (CA) ordination plot indicates that all the periphytic algal families fall within the $95 \%$ ellipse region and most of the families were distributed around stations 4 and 5 (Figure 6).
Cluster analysis based on the Bray Curtis similarity index resulted in a dendrogram which shows a total of $68 \%$ similarity between selected stations (Figure 7). Stations 4 and 5 located in the lower reaches showed $81 \%$ similarity in the periphytic algal composition. Stations 1 and 2 showed $73 \%$ of similarity while S3, the center lying station forms an outlier and shows the least similarity $(68 \%)$ with other stations.

The nature of the habitat and the hydrological conditions existing in an area clearly defines the composition of organisms present in that locality. Estimation of periphytic algal abundance among selected stations showed that station 4 harbors more species and station 3 harbors the least number of species. The ordination plot resulted from CA analysis also showed that most of the families were distributed around stations 4 and 5. Station 4, Aluva is a major industrial center and an important commercial town. Periyar river flowing through the Aluva region receives a considerable amount of organic and inorganic pollution load from nearby industries and towns which accounts for the increased nitrate and phosphate content in this station (Joseph, 2004, KSPCB, 1981). Domestic sewage discharge and increased anthropogenic activities result in nutrient enrichment and the corresponding increase in periphytic algal production (Dhanasekaran et al., 2016; Joseph, 2017). Dendrogram resulted from cluster analysis of the algal assemblages from selected stations showed $70 \%$ of similarity in species composition of periphytic algae among selected stations although their number may vary between stations.

\section{Substrate Wise Distribution of Periphytic Algae}

Percentage abundance of substrate wise distribution of periphytic algae follows the order leaf $>$ root $>\log >$ wall $>$ rock (Figure 8). Leaf harbor maximum number of periphytic algae with $34.46 \%$ of abundance followed by root $(22.70 \%)$. Rock was the least preferred substrate with only $9 \%$ of abundance. Fragilaria capucina, F. virescens, Synedra ulna, Gomponema grunowii, Navicula protracta, N. microspora, Pinnularia viridis and Tabellaria flocullosa were the most dominant species found on leaf substratum.

The ordination plot resulted from correspondence analysis illustrates the distribution of periphytic algal families along the selected substrate. All families except Chrococcaceae, Phormidaceae, and Amphipleuraceae fall in the 95\% ellipse region and most of the families prefer leaf as their preferred substrate for colonization (Figure 9).

Dendrogram drawn based on the cluster analysis between different substrata resulted in two groups with a total of $72 \%$ of similarity. Log and wall $(86 \%)$ showed 
a higher percentage of similarity in periphytic algal composition followed by leaf and root $(85 \%)$ whereas rock forms an outlier showing the least similarity with the rest of the substrate (Figure 10).

Substrate plays a crucial role in the colonization and composition of periphytic algae compared to planktonic forms. All substrata are highly dynamic in their physical characteristics and functional interactions with the attached biota. Most of the periphytic algal forms are seen in the littoral zones of lotic systems and are easily encountered by all types of contaminants that originate from the nearby land area (Kanavillil \& Kurisseryl, 2013). These littoral areas possess different substrata like rock, leaf, wall, and log where periphytic algae can easily attach and grow. Estimation of percentage abundance of periphytic algae among different substrata showed the abundance of periphyton in leaf followed by root. The correspondence analysis plot also shows the importance of leaf as a suitable substratum for colonization. Periphytic algal mat is developed from the propagules of planktonic forms; leaves are continuously facing the water currents and due to its large surface area these planktonic propagules can easily attach and colonize (Kanavillil \& Kurisseryl, 2013). Most of the periphytic algal assemblages choose leaf as their preferred substratum because of the large surface area, easy colonization, and attachment using specific modifications.

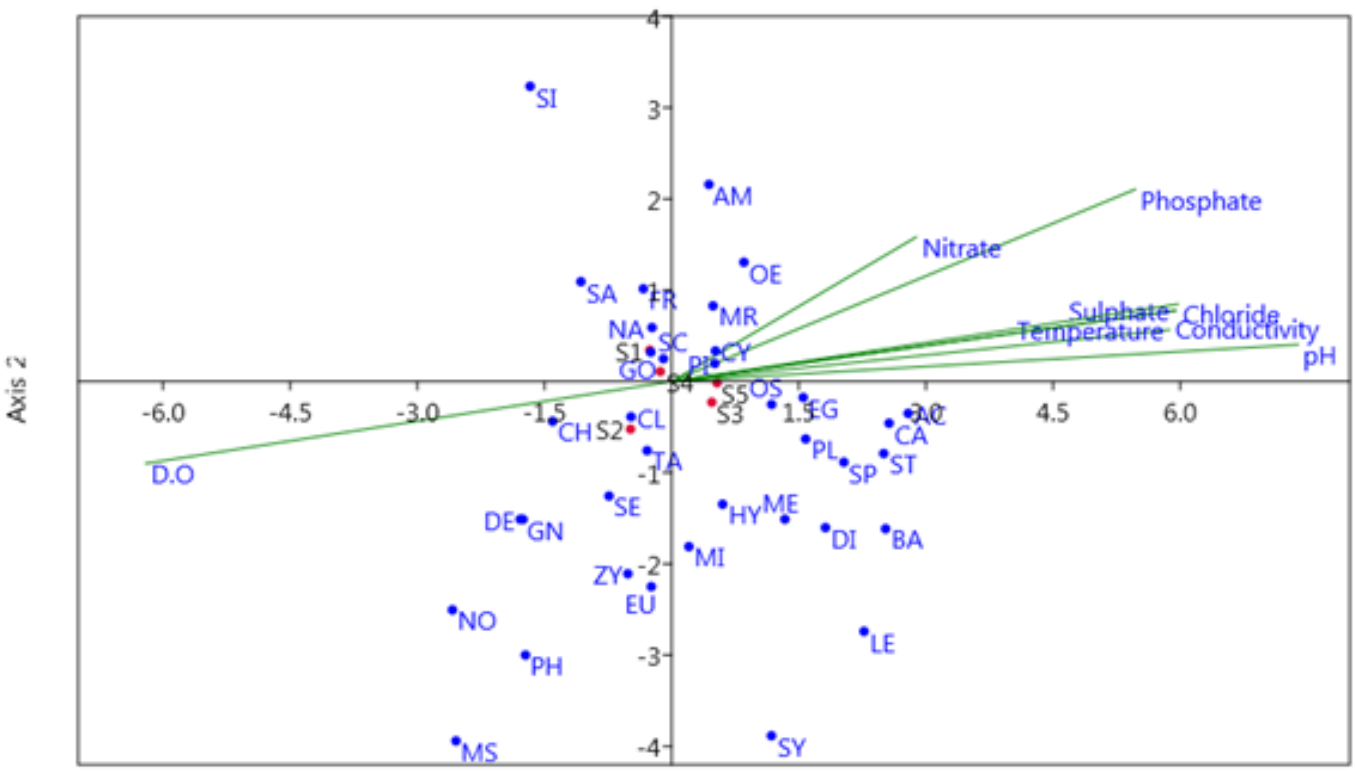

Axis 1

Figure 4. CCA ordination plot depicting the relationship between environmental parameters and algal assemblages. Environment variables were represented by vectors radiating from the origin. Algal families were represented by dots on the plot (abbreviations given in table2). Red dots denote selected stations (S1-station 1, S2-station 2, S3-station 3, S4station 4, S5- station 5). 


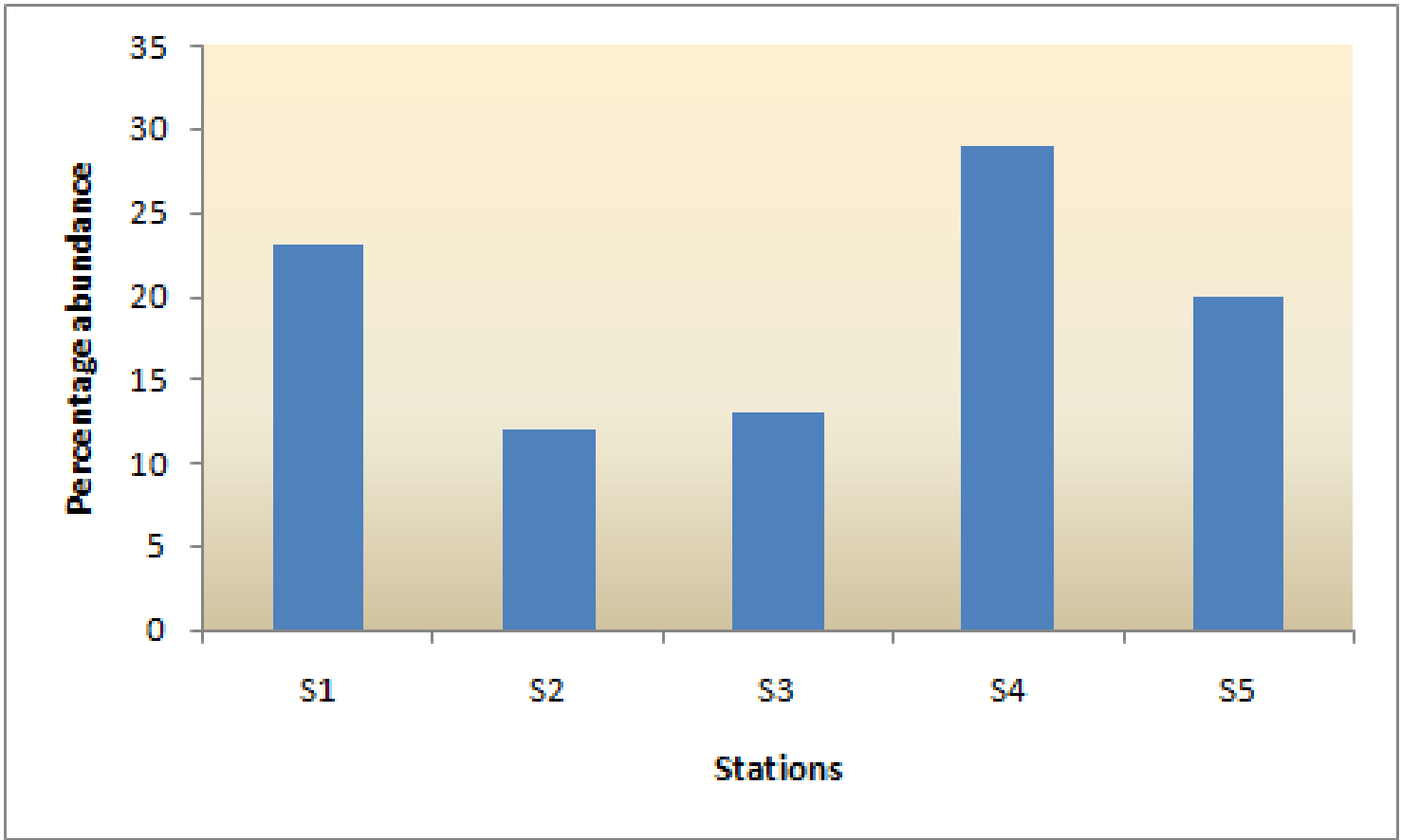

Figure 5. Percentage abundance of periphytic algae from selected stations of river Periyar

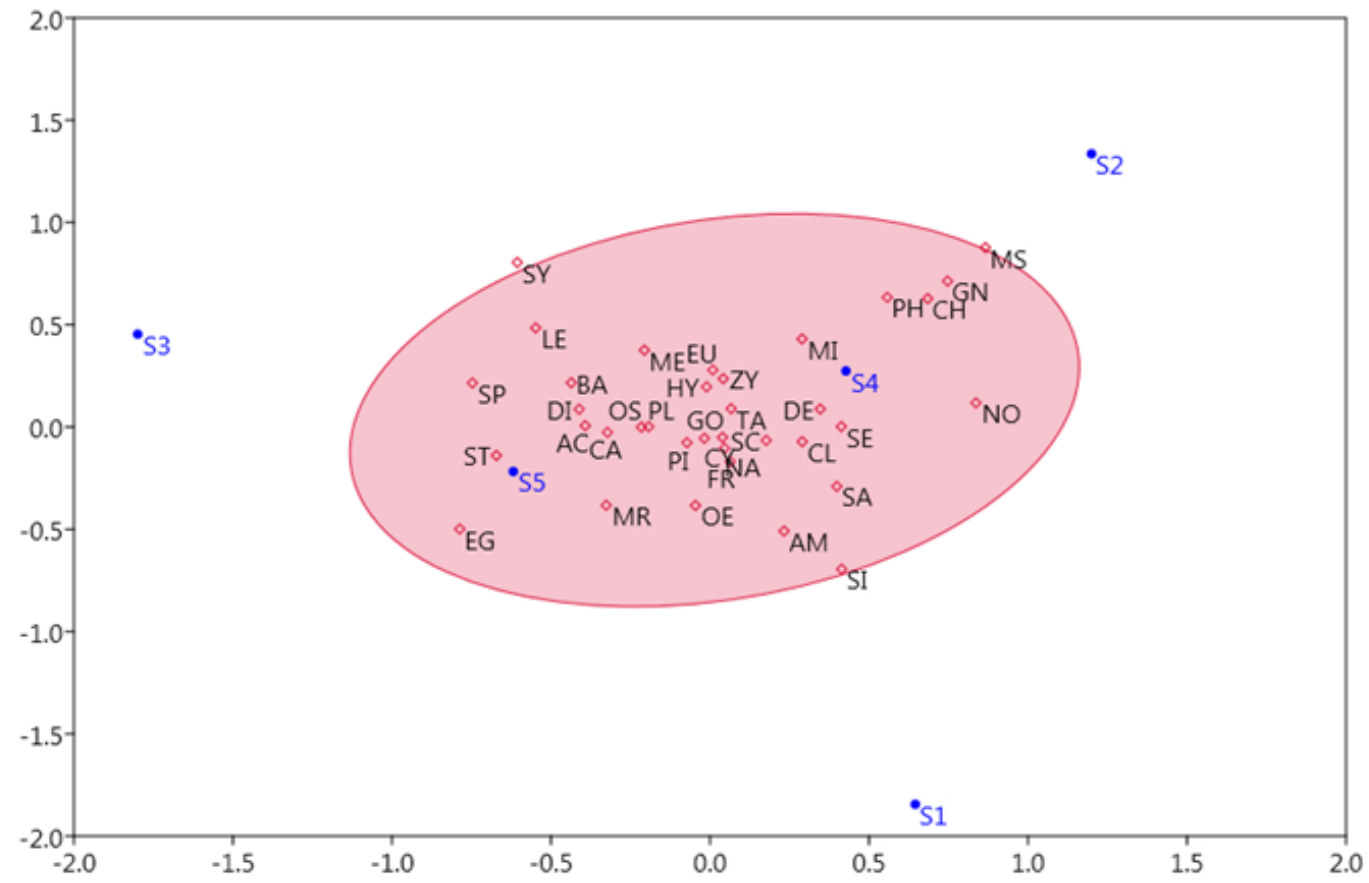

Figure 6. CA ordination plot depicting the distribution of periphytic algal families on selected stations. The ellipse encloses $95 \%$ confidence level. Diamond denotes periphytic algal families (abbreviations for were provided in table 2). Stations were represented by dots on the plot (S1-station 1, S2-station 2, S3-station 3, S4- station4, S5-station 5) 


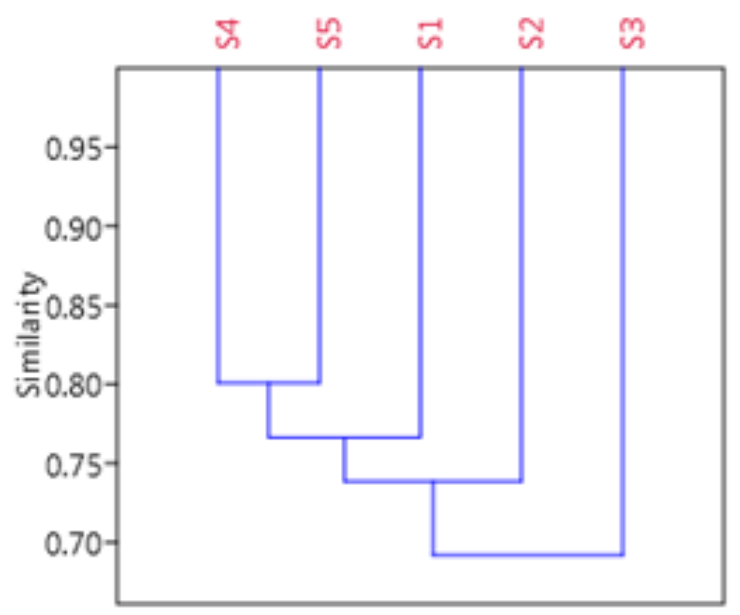

Figure 7. Dendrogram(UPGMA) based on Bray Curtis similarity index depicting the taxonomic composition of periphytic algal families along with different stations

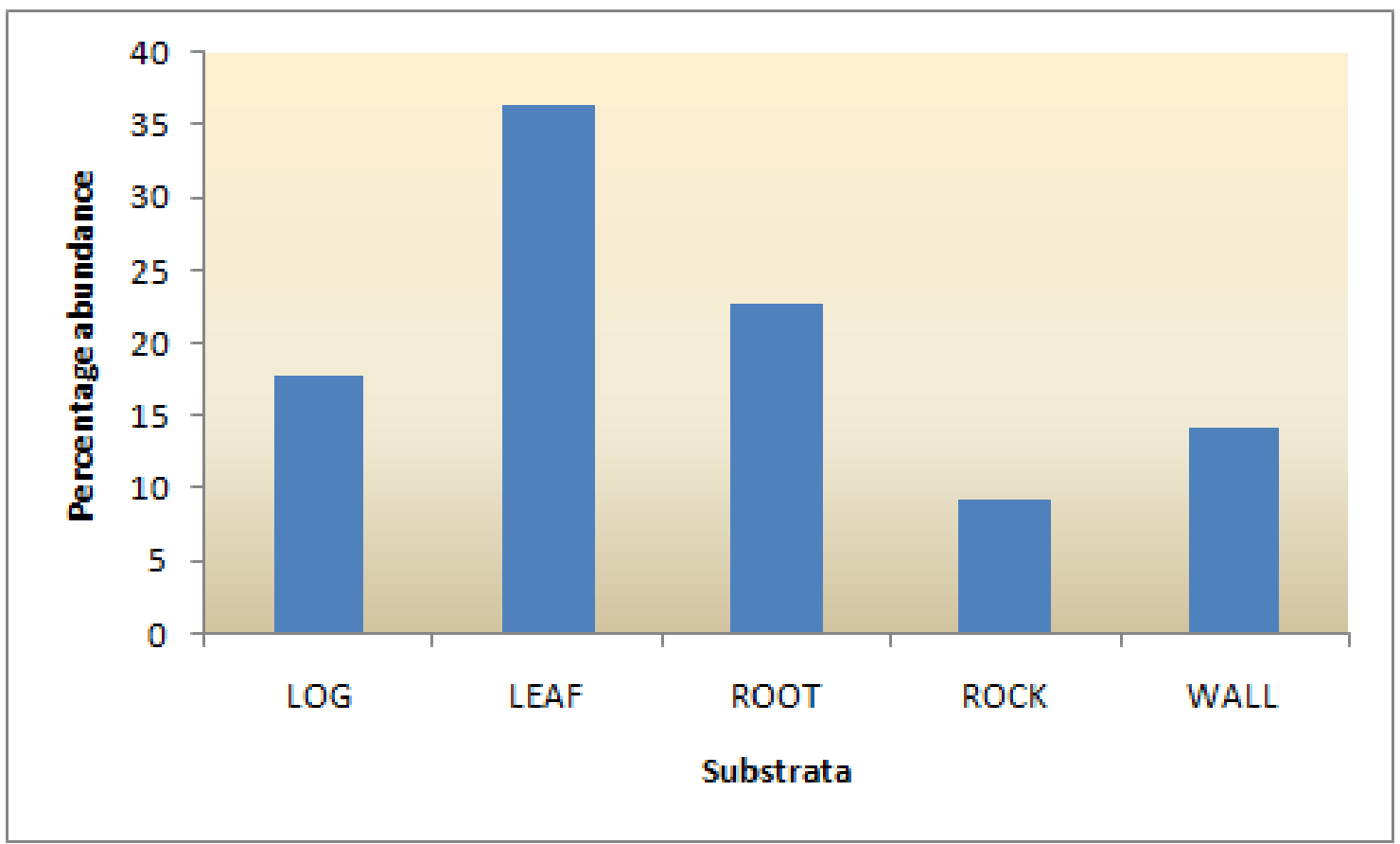

Figure 8. Percentage abundance of periphytic algae from different substrata of river Periyar 


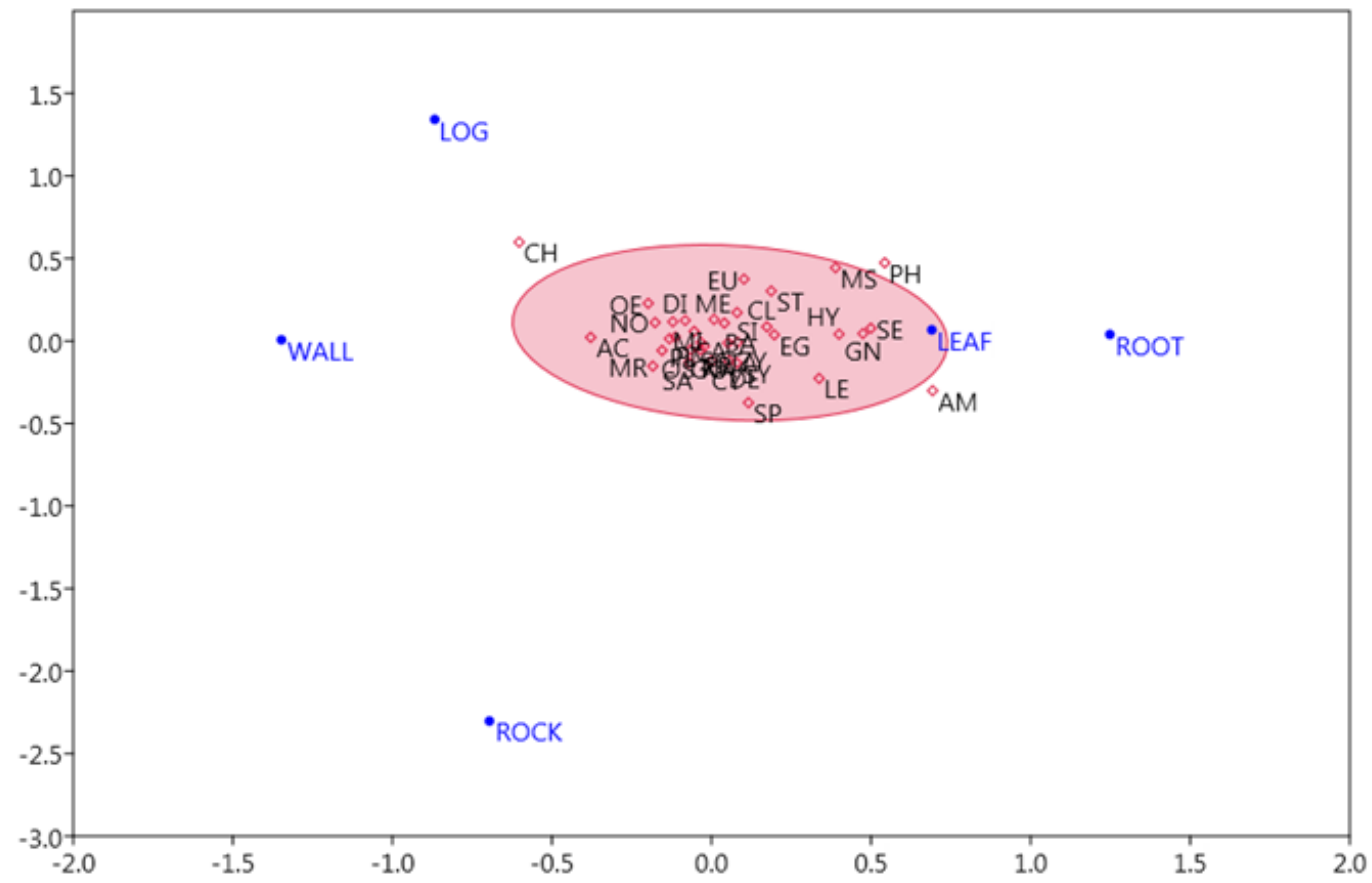

Figure 9. CA plot depicting the distribution of periphytic algal families along the selected substrate. The ellipse encloses $95 \%$ confidence level. Periphytic algal families were represented by the diamond symbol (abbreviations for were provided in table 2). Dots on the plot denote different substrata.

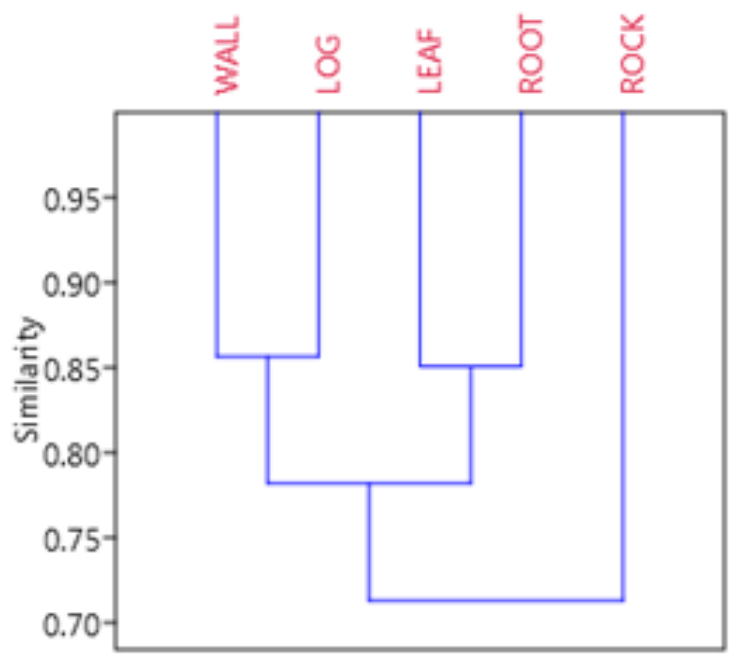

Figure 10. Dendrogram (UPGMA) based on Bray Curtis similarity index depicting the taxonomic composition of periphytic algae on varying substrate. 


\section{Conclusion}

Algae possess a pivotal space among periphytic organisms. Due to its photoautotrophic nature algae acts as a power source for the whole periphytic biota and a regulator for nutrient fluxes. Its short life cycle and the ability to respond to slight environmental variations make periphytic algae as a good bioindicator. The present study deals with species composition, substrate specificity, and environmental preference of periphytic algae of river Periyar. The maximum abundance of periphytic algae was reported from station 4 , which also experienced the maximum nutrient load. Most of the periphytic algal species choose leaf as their preferred substratum followed by root and log. PCA revealed the dominance of Naviculaceae and Fragilariaceae families in the pre-monsoon period. CCA illustrates that the combined actions of several environmental variables like $\mathrm{pH}$, conductivity, sulfate, temperature, phosphate, and DO determine the periphytic algal composition, diversity, and richness along river Periyar. Since adequate and accurate information regarding periphytic algae of river Periyar is too scarce, the data obtained will serve as a base-line for future studies.

\section{Compliance with Ethical Standard}

Conflict of interests: The authors declare that for this article they have no actual, potential or perceived conflict of interests.

Ethics committee approval: All authors declare that this study does not include any experiments with human or animal subjects.

Funding disclosure: This study is a part of the first author's Ph.D. thesis which has been supported by University Junior Research Fellowship (4677/A6/2/JRF2017/Acd) under Mahatma Gandhi University, Kottayam

Acknowledgments: The authors would like to thank the Principal, Catholicate College, Pathanamthitta for providing the facility to carry out the research work.

Disclosure: -

\section{References}

Albay, M., Akcaalan, R. (2008). Effects of water quality and hydrologic drivers on periphyton colonization on Sparganium erectum in two Turkish lakes with different mixing regimes. Environmental Monitoring and Assessment, 146, 171181.

https://doi.org/10.1007/s10661-007-0069-5

Adhikary, S.P., Das, S. K. (2012). Freshwater Algae of Eastern India. Daya Publishing House.

Ansari, E., Gadhia, M., Ujjania, N.C. (2015). Phytoplankton diversity and water quality assessment of ONGC pond, Hazira. International Journal of Research in Environmental Science, 1(1), 1-15.

APHA. (21 ${ }^{\text {st }}$ Ed.). (2005). Standard methods for the examination of water and wastewater. American Public Health Association. ISBN: 0875530478

Biggs, B.J.F. (1996). Patterns in benthic algae of streams. Algal Ecology: freshwater benthic ecosystems. Academic Press. ISBN: 9780126684506 https://doi.org/10.1016/B978-012668450-6/50031-X

Biggs, B.J.F, Kilroy, C. (2000). Stream periphyton monitoring manual. The New Zealand Ministry for the Environment, NIWA. ISBN: 0-478-09099-4

Cetto, J.M., Felisberto, A.S., Leandrini, J.A., Rodrigues, L. (2004). Periphyton algae community in Irai reservoir, Paraná state, Brazil. Acta Scientiarum. Biological Sciences, 26, 1-7.

https://doi.org/10.4025/actascibiolsci.v32i1.3764

De Souza, M.L., Ferragt, C., Pellegrini, B.G. (2015). Periphytic algal community structure in relation to seasonal variation and macrophyte richness in a shallow tropical reservoir. Hydrobiologia, 755, 183-196.

https://doi.org/10.1007/s10750-015-2232-2

Dhanasekaran, M., Bhavan, S.P., Manickam, N., Kalpana, R. (2016). Physico-chemical characteristics and zooplankton diversity in a perennial lake at Dharmapuri. Journal of Entomology and Zoology Studies, 5(10), 285-292.

Edmondson, W.T. (2 ${ }^{\text {nd }}$ Ed.). (1959). Freshwater Biology. John Wiley and Sons Inc. ISBN: 978-04-71232988

Franca, R.C.S., Lopes, M.R.M., Ferragut, C. (2011). Structural and successional variability of periphytic algal 
community in a Amazonian lake during the dry and rainy season. Acta Amazonica, 4(2), 257-266.

http://dx.doi.org/10.1590/S0044-59672011000200010

Gurumayum, S.D., Goswami, U.C. (2013). Studies on seasonal and topographical variations of periphyton in the rivers of Manipur. Journal of Environmental Biology, 34, 599-604.

Hajong, P., Ramanujam, P. (2018). Seasonal variation in algal diversity and productivity in Dachilake, Meghalaya. Journal of Algal Biomass Utilization, 9(2), 9-24.

John, J., Francis, M. S. (2012). An Illustrated Algal Flora of Kerala, Vol. 1, Idukki District. GCS Books. ISBN: 9789385657054

Joseph, J. (2017). Diversity and distribution of phytoplankton in an artificial pond. International Journal of Advance Research in Biological Sciences, 4(5).

http://dx.doi.org/10.22192/ijarbs.2017.04.05.013

Joseph, M.L. (2004). Status report on Periyar river: The declining trend of biodiversity and fish production in consequence of pollution in the lower reaches of Periyar river. Report of the Kerala Research Programme for Local Level Development. Thiruvananthapuram: Centre for Development Studies.

Kanavillil, N., Kurisseryl, S. (2013). Temporal variation of periphyton communities: a 3- year study from northwest lake Simcoe, Ontario, Canada. Inland Waters, 3(4), 437-486.

https://doi.org/10.5268/IW-3.4.525

Kaparapu, J., Geddada, M.N.R. (2013). Seasonal distribution of phytoplankton in Riwada reservoir, Visakhapatnam, Andhra Pradesh, India. Notulae Scientia Biologicae, 5(3), 290-295.

https://doi.org/10.15835/nsb539082
Karthick, B., Hamilton, P. B., Kociolek, J.P. (2013). An illustrated guide to common diatoms of Peninsular India. Gubbi Labs, Gubbi, 206 pp.

KSPCB. (1981). Periyar action plan, phase - 1, status survey and project identification.

Oterler, B. (2016). Longitudinal and seasonal succession of algal periphyton colonization in Lowland River. Peer $J$ Prints,

https://doi.org/10.7287/peerj.preprints.1953v1

Rusanov, A.G., Stanislavskaya, E.V. (2012). Periphytic algal assemblages along environmental gradients in the rivers of the lake Ladoga basin, Northwestern Russia: implication for the water quality assessment. Hydrobiologia, 695, 305327.

https://doi.org/10.1007/s10750-012-1199-5

Satkauskiene, I., Glasaite, R. (2013). Periphyton composition and diversity in the Kaunas lagoon and Nemunas river. Biologija, 59(2), 141-150.

https://doi.org/10.6001/biologija.v59i2.2746

Sohani, S. (2015). Diversity of freshwater algae in river Narmada at Jalud (Mandleswer), Indore, India. Research Journal of Recent Sciences, 4, 14-17.

Srivastava, K., Alam, A., Das, S.C.S., Joshi, K.D., Thakur, V.R. (2019). Biodiversity and spatio-temporal variation of periphyton of the river Ganga (Gangotri to Vidhyachal). International Journal for Fisheries and Aquatic Studies, 7(1), 109-115.

Wu, Y. (2017). Periphyton: functions and application in environmental remediation. Elsevier, 1-48. ISBN: 978-0-12801077-8 